Захист і карантин рослин. 2019. Вип. 65.

УДК 631.1:001.76 + 632.9:633.1

DOI: https://doi.org/10.36495/1606-9773.2019.65.3-16

\author{
О.І. БОРЗИХ, доктор сільськогосподарських наук \\ М.В. КРУТЬ, кандидат біологічних наук \\ Інститут захисту рослин НААН, вул. Васильківська, 33, м. Київ, 03022, \\ Україна, e-mail:m.v.krut@ukr.net
}

\title{
БАЗА ДАНИХ ІННОВАЦІЙНИХ РОЗРОБОК ІЗ ЗАХИСТУ ЗЕРНОВИХ КУЛЬТУР В УКРАЇНІ
}

Мета. Проаналізувати інноваційні розробки із захисту зернових культур в Україні і на підставі цього сформувати інвестиційно-інноваційну базу даних. Методи. Аналіз інноваційних розробок Інституту захисту рослин Національної академії аграрних наук України та інших установ Науково-методичного центру «Захист рослин» за 2001-2018 рр. Виділення тих із них, що стосуються захисту зернових культур від шкідників, хвороб та бур'янів. Групування інновацій із захисту зернових культур за напрямами. Результати. Створено інвестиційно-інноваційну базу даних із захисту зернових культур в Україні. Вона складається із 155-ти наукових розробок, що згруповані за такими напрямами: прогнозування фітосанітарного стану посівів; наукове забезпечення селекції зернових культур на стійкість проти шкідників та хвороб; біологічний метод захисту рослин; вдосконалені екологічно безпечні технології захисту зернових культур від шкідливих організмів; хімічний метод захисту рослин; карантин рослин. Ефект від трансферу інновацій може бути таким: чистий прибуток від 3367-7950 до 12644,5 грн на 1 га (за умов зрошення), рентабельність - від 84,1 до 131-152\%. Висновки. Результатом здійснення трансферу створених інновацій є ефективний захист найважливіших зернових культур (пшениия, жкито, ячмінь, горох, гречка, просо, кукурудза, соя) від шкідливих організмів у різних грунтово-кліматичних зонах України і разом 
із тим - одержання значної частини додаткової продукиії покращеної якості та підвищення рентабельності виробництва. Це буде підставою для успішного вирішення цілої низки проблем щодо зміцнення як зернового господарства, так і аграрного сектору та економіки країни в цілому.

\section{інвестиційно-інноваційна база даних, зернові культури, шкідливі організми, прогноз, стійкість проти шкідників та хвороб, біологічний метод, хімічний метод, екологічно безпечні технології захисту, карантин рослин}

Стратегічною і найбільш ефективною галуззю вітчизняної економіки є зернове господарство. Середній обсяг виробництва зерна за 2006-2010 рр. в країні становив 40,4 млн т, або 879 кг на душу населення. Значно зросли валові збори цієї продукції в 2008, 2009 та 2011 рр. - відповідно до 53,3, 46,0 та 56,7 млн т. У 2013-2017 рр. вони були на більш високому рівні - 60,1-64,2 млн т. А в 2018-2019 pр. зібраний врожай зерна в Україні вже перейшов рубіж 70 млн т. Нині наша країна забезпечує $3 \%$ світового виробництва зерна і більш як $10 \%$ світового експорту.

Програмою «Зерно України» передбачено найближчим часом вийти на щорічний обсяг виробництва зерна в країні на рівні 80 млн т. Це цілком реально, якщо врахувати посівні площі основних зернових культур (пшениця озима -6 млн га, ячмінь озимий і ярий $-3,3$, кукурудза - 3,5 млн га) та їхню потенційну продуктивність у межах $70 \%$ [1].

Проте погодні умови (потепління клімату) та господарські чинники (виведення сотень тисяч гектарів землі з господарського використання, порушення сівозмін, нестача техніки й пально-мастильних матеріалів, хімічних та біологічних засобів захисту тощо) часто є причиною загострення фітосанітарного стану посівів зернових. За цих умов мають місце масові розмноження та висока шкідливість шкідників, збудників хвороб рослин та бур'янів, через що недобори врожаїв зерна можуть сягати 30 і навіть 50\% [1-4]. Отже, захист зернових культур від шкідливих організмів $є$ важливим резервом для одержання значної частини додаткової продукції покращеної якості.

Одним із чинників, що стримують стабільний розвиток зернового господарства країни, є також низький рівень наукового забезпечення галузі, зокрема відсутність цілісних інноваційних баз даних із захисту зернових культур. Але широке впровадження наукових досягнень дозволяє знизити потенційні недобори врожаїв на 70-75\%, пестицидне навантаження на агроекосистему - на 30\% [5].

Мета роботи полягала в аналізі інноваційних розробок із захисту зернових культур в Україні і на підставі цього - створенні інвестиційно-інноваційної бази даних. 
Методика досліджень. Матеріалами для дослідження служили інноваційні розробки Їнституту захисту рослин Національної академії аграрних наук України та інших установ Науково-методичного центру «Захист рослин» за 2001-2018 рр. За аналізу виділяли ті розробки, які безпосередньо стосуються захисту зернових культур від шкідників, хвороб та бур'янів. ІІнновації із захисту зернових культур групували за тими чи іншими напрямами.

Результати досліджень. Працюючи за програмою наукових досліджень «Захист рослин», Іेнститут захисту рослин та інші установи НААН були задіяні у створенні інновацій захисту рослин. На підставі аналізу роботи, виконаної протягом 2001-2018 рр., сформовано інвестиційно-інноваційну базу даних наукових розробок із захисту рослин в Україні. Ця база даних складається із 317-ти інноваційних розробок, майже $50 \%$ із яких стосуються проблеми захисту зернових культур. Їнновації захисту зернових культур згруповані за напрямами: прогнозування фітосанітарного стану посівів; наукове забезпечення селекції зернових культур на стійкість проти шкідників та збудників хвороб; біологічний метод захисту рослин; вдосконалені екологічно безпечні технології захисту зернових культур від шкідливих організмів; хімічний метод захисту рослин; карантин рослин (табл.).

1. Прогнозування фітосанітарного стану посівів. Основою для планування та проведення робіт із захисту рослин, визначення потреби в хімічних засобах, а також матеріальних і трудових затрат є прогноз. Треба враховувати й те, що підвищення температури повітря останніми роками призвело до зміни тривалості сезонів року і, відповідно, розвитку сільськогосподарських культур. Разом із тим змінюється екологічний оптимум різних видів шкідливих організмів рослин, зони оптимуму для них поширюються на північ, у зв'язку з чим щільність популяції шкідників збільшується [6]. Наслідком загострення фітосанітарного стану агроценозів $\epsilon$ майже третина, а інколи й половина недоборів урожаїв вирощуваних культур, зокрема зернових. В цих умовах величезного значення набуває оперативне та достовірне прогнозування розвитку комплексу шкідливих організмів на рослинах, можливих недоборів урожаїв від них з метою розробки та своєчасного проведення ефективних захисних заходів.

Їнститутом захисту рослин та іншими установами НААН (табл.) впродовж останніх 18-ти років створено 13 інновацій з питань прогнозування фітосанітарного стану посівів зернових культур. Вони стосуються здійснення феромонного моніторингу лускокрилих шкідників (совки, кукурудзяний метелик), комп'ютерного прогнозування розвитку плямистостей листя зернових культур, недоборів урожаю пшениці озимої, кукурудзи, сої та доцільності застосування засобів захисту рослин, проведення моніторингу токсигенності та патоген- 
Інвестиційно-інноваційна база даних наукових розробок із захисту зернових культур в Украйні (2001-2018 рр.)

\begin{tabular}{|c|c|c|c|}
\hline $\begin{array}{c}\text { № } \\
\text { II/ா }\end{array}$ & $\begin{array}{l}\text { Інноваційний } \\
\text { напрям }\end{array}$ & 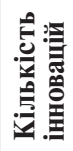 & Установи-виконавці \\
\hline 1 & $\begin{array}{l}\text { Прогноз } \\
\text { фітосанітарного стану } \\
\text { посівів }\end{array}$ & 13 & $\begin{array}{l}\text { І̇нститут захисту рослин, Миронівський ін- } \\
\text { ститут пшениці ім. В.М. Ремесла, Полтав- } \\
\text { ська державна сільськогосподарська дослід- } \\
\text { на станція ім. М.Іे. Вавилова, Закарпатська } \\
\text { ДСГДС, Прикарпатська ДСГДС НААН }\end{array}$ \\
\hline 2 & $\begin{array}{l}\text { Наукове } \\
\text { забезпечення селекції } \\
\text { сільськогосподарських } \\
\text { культур на стійкість } \\
\text { проти шкідників та } \\
\text { збудників хвороб }\end{array}$ & 29 & $\begin{array}{l}\text { Їнститут захисту рослин, Українська науко- } \\
\text { во-дослідна станція карантину рослин ЇЗР } \\
\text { НААН, Миронівський інститут пшениці } \\
\text { ім. В.М. Ремесла, ННЦ «Їнститу землероб- } \\
\text { ства НААН», Їнститут олійних культур, Іेн- } \\
\text { ститут сільського господарства Карпатського } \\
\text { регіону, Іेнститут рису НААН }\end{array}$ \\
\hline 3 & $\begin{array}{l}\text { Біологічний метод } \\
\text { захисту рослин }\end{array}$ & 8 & $\begin{array}{l}\text { Їнститут захисту рослин, Українська дослід- } \\
\text { на станція карантину рослин ЇЗР НААН, } \\
\text { Іेнститут сільськогосподарської мікробіоло- } \\
\text { гії та агропромислового виробництва, За- } \\
\text { карпатська державна сільськогосподарська } \\
\text { дослідна станція НААН }\end{array}$ \\
\hline 4 & $\begin{array}{l}\text { Вдосконалені } \\
\text { екологічно безпечні } \\
\text { технології захисту } \\
\text { зернових культур } \\
\text { від шкідливих } \\
\text { організмів: } \\
\text { а) захист рослин від } \\
\quad \text { нематодозів; } \\
\text { б) проблеми гербології } \\
\quad \text { в захисті зернових } \\
\quad \text { культур; } \\
\text { в) захист зернових } \\
\quad \text { культур від } \\
\quad \text { шкідників, хвороб } \\
\quad \text { та бур'янів; } \\
\text { г) захист зерна при } \\
\quad \text { зберіганні }\end{array}$ & 57 & 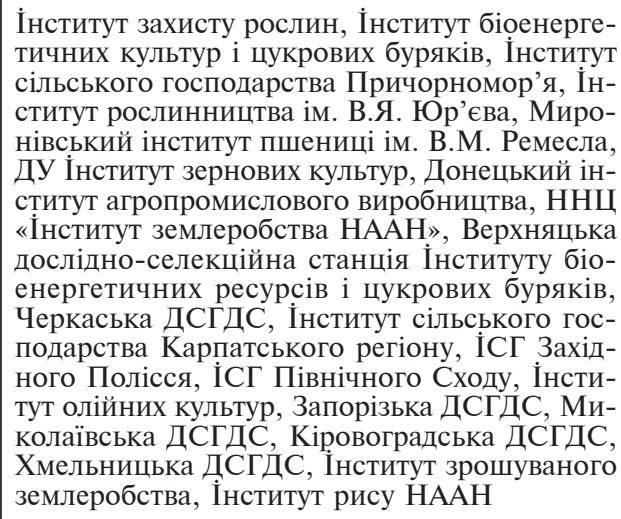 \\
\hline 5 & $\begin{array}{l}\text { Хімічний метод } \\
\text { захисту рослин }\end{array}$ & 19 & $\begin{array}{l}\text { Іेнститут захисту рослин, } \\
\text { Іेнститут рису НААН }\end{array}$ \\
\hline 6 & Карантин рослин & 29 & $\begin{array}{l}\text { І̇нститут захисту рослин НААН та його мере- } \\
\text { жа - Дослідна станція карантину винограду } \\
\text { і плодових культур, Закарпатський територі- } \\
\text { альний центр карантину рослин, Українська } \\
\text { науково-дослідна станція карантину рослин }\end{array}$ \\
\hline
\end{tabular}


ності грибів Fusarium sp. на зернових культурах, створення бази багаторічних даних динаміки заселення сільськогосподарських культур багатоїдними шкідниками, прогнозування фітосанітарного стану агроценозів України в умовах року та розробки рекомендацій щодо захисту рослин. Широке використання інновацій науковими установами та Державною службою України з питань безпечності харчових продуктів та захисту споживачів (Держпродспоживслужба України) розкриває можливості вирішення важливих питань щодо розробки достовірних багаторічного, дострокового та короткострокового прогнозів фітосанітарного стану агроценозів зернових культур, уникнення можливих спалахів чисельності шкідників, зменшення трудовитрат на процес прогнозування, збереження 10-20\% урожаю та охорони навколишнього середовища.

2. Наукове забезпечення селекції зернових культур на стійкість проти шкідників та збудників хвороб. За останні 10-15 років різко змінились форми ведення господарства і разом із тим технології вирощування сільськогосподарських культур. На заміну 8- та 10-пільним сівозмінам прийшли 3-4-пільні, і це скоротило період ротації культур у сівозміні вдвічі [7]. Внаслідок цього фітосанітарний стан посівів зернових культур може також погіршуватись.

Особливого значення набуває система інтегрованого захисту рослин. Найбільш рентабельним й екологічно безпечним у цій системі захисту є використання стійких до пошкоджень сортів та гібридів з урахуванням об'єктів, проти яких ці ознаки спрямовані, а також рівня стійкості. На високостійких сортах розмноження шкідників та поширення збудників хвороб можуть стримуватись навіть в умовах, що сприяють їхньому розвитку. Середньостійкі сорти можуть протистояти шкідливим організмам тільки за слабкого й середнього ступеня їх розмноження. За масової появи шкідників або епіфітотійного розвитку хвороб на таких посівах треба додатково застосовувати засоби захисту, але при цьому норми витрати пестицидів і кількість обробок можуть бути скорочені [8].

Враховуючи зазначене, вчені Їнституту захисту рослин та інших установ НААН значну увагу приділяють селекції основних сільськогосподарських культур на стійкість проти шкідників та збудників хвороб. Зокрема, результатом 29-ти інноваційних розробок став величезний потенціал щодо створення стійких сортів зернових культур. Розроблено методи селекції стійких рослин проти збудників хвороб, які враховують наявність бази даних расового складу основних збудників хвороб пшениці та ячменю в різних грунтово-кліматичних зонах України, бази даних складу генів вірулентності основних збудників хвороб, бази даних відомих генів стійкості культур, методику створення та застосування комплексних штучних інфекційних фонів для селекції 
пшениці на групову стійкість. Створено та передано до Національного центру генетичних ресурсів рослин України бази даних ефективних генів стійкості пшениці до місцевої популяції збудника бурої іржі та джерел резистентності до дії збудників бурої іржі, септоріозу, борошнистої роси. Досліджено ювенільну стійкість зразків перспективних ліній вихідних ланок селекції пшениці озимої до збудників бурої іржі, борошнистої роси, септоріозу, церкоспорельозу. Розроблені методичні рекомендації з визначення стійкості зернових до високих та низьких температур дають підстави для створення сортів, стійких до негативної дії абіотичних чинників та проти збудників грибних хвороб. В наявності також: а) джерела стійкості сої, рису, вівса до збудників основних хвороб; б) бази даних генів стійкості пшениці та ячменю до тих чи інших рас збудників основних хвороб; в) методики використання механізмів стійкості сортозразків пшениці та рису проти основних шкідників; г) колекція зразків дикого родича пшениці Aegilops biuncilais L. - джерел нових генів стійкості проти хвороб та шкідників; д) методики використання генофонду стійких проти збудників хвороб та шкідників м'яких пшениць у селекційних програмах; е) колекція ліній сої за ознакою комплексної стійкості проти білої гнилі та антракнозу; є) база даних про стійкість сортів і селекційних зразків сої до вірулентних штамів (рас) Fusarium oxysporum, Colletotrichum gloesporioides, Pseudomonas savastanoi pv. glucinea, Xanthomonas axonopodis ph. glucinea, Peronospora manschurica; ж) методики оцінки стійкості пшениці проти вірусних захворювань. Всі ці наукові досягнення можуть успішно використовуватись селекційними центрами та іншими науковими установами в селекційній роботі.

3. Біологічний метод захисту рослин. Для вирішення проблеми кардинального покращення екологічної ситуації в Україні потрібний постійний пошук можливостей зменшення пестицидного навантаження на агроценози та підвищення безпеки для навколишнього середовища. Тому в комплексних системах заходів захисту рослин значну увагу слід приділяти біологічним методам, які грунтуються на використанні паразитичних і хижих комах та кліщів, хвороботворних мікроорганізмів, інших біотичних факторів. Перевага біологічних методів полягає у збереженні та розмноженні паразитів, хижаків, збудників хвороб у природних умовах, що призводить до тривалого обмеження чисельності шкідників вирощуваних культур [9].

Вченими Їнституту захисту рослин та його мережі, Їнституту сільськогосподарської мікробіології та агропромислового виробництва, Закарпатської державної сільськогосподарської дослідної станції НААН створено 8 інновацій стосовно біологічного методу захисту зернових культур (табл.). На основі ентомопатогенного штаму бактерії Bacillus thuringiensis 0293 розроблено лабораторний регламент вироб- 
ництва рідкого біопрепарату, у якого широкий спектр ефективної дії проти шкідників ряду Lepidoptera. Виявлено можливості застосування мікробіопрепарату Хетомік (на основі природного штаму гриба-антагоніста Chaetomium cochioides 3250) для захисту пшениці ярої від збудників гельмінтоспоріозної й фузаріозної гнилей. Вказано на доцільність сумісного використання фізичних методів із бактеріальними препаратами для передпосівної обробки насіння ячменю й пшениці ярої проти збудників хвороб рослин та для покращання якості зерна. Встановлено ефективність різних поєднань біопрепарату на основі бактерій Pseudomonas flurenscens з оптимальними концентраціями речовин групи амонійних солей дигідропірімідину й композицій мікроелементів за обробки посівів сої - зниження розвитку фузаріозу, аскохітозу, септоріозу на 55-76\%.

Розроблено критерії ефективності домінуючих природних ентомофагів проти попелиць, кукурудзяного метелика та совок на кукурудзі. Удосконалений екологічно безпечний метод регуляції чисельності лускокрилих шкідників кукурудзи базується на використанні трихограми Trichogramma evanescens Westw. місцевої популяції та врахуванні дії природних ентомофагів. Все це дає змогу підвищити ефективність захисту культури на 20-25\%, зменшити кількість обробок посівів, зекономити кошти на проведення захисних заходів на 35-50\%.

Таким чином, здійснення трансферу інновацій із застосування біологічних засобів у захисті зернових культур дасть широкі можливості розширення до 25-30\% їх площ в органічному землеробстві для виробництва високоякісної продукції та утримання в чистоті довкілля.

4. Вдосконалені екологічно безпечні технології захисту зернових культур від шкідливих організмів. Грунтово-кліматичні умови України здебільшого сприятливі для вирощування високих урожаїв високоякісного зерна пшениці, жита, ячменю, гороху, гречки, проса, кукурудзи, сої та інших культур. Але для цього потрібно впроваджувати сучасні інтенсивні технології виробництва, складовими яких є інтегрована система захисту рослин від шкідників, хвороб та бур'янів.

У сучасному розумінні інтегрований захист рослин - це виважене використання комплексу методів на основі оцінки структури популяції шкідливих організмів та можливостей природних регулюючих чинників в агроценозі, а також визначення ступеня загрози для культури від них з метою обмеження шкідливості до економічно невідчутного рівня. Важливими складовими інтегрованого захисту рослин є оцінка агрофону й фітосанітарного стану поля, прогнозування розмноження й шкідливості комплексу шкідливих організмів, дотримання економічних порогів шкідливості.

Великого значення, як вже зазначалося, набуває використання стійких до пошкоджень сортів та гібридів. Треба також приділяти 
увагу комплексу агротехнічних заходів (дотримання науково обгрунтованого чергування культур у сівозмінах, правильна система удобрення та система основної й передпосівної підготовки грунту, якісно підготовлений насіннєвий матеріал, оптимальні строки сівби, способи, норми висіву, глибина загортання насіння), заходам щодо догляду за посівами, використанню можливостей біологічного методу. Заключним важливим елементом інтегрованого захисту є застосування пестицидів, яке має бути найбільш виваженим з урахуванням можливостей усіх інших методів, видового складу шкідливих організмів, ступеня загрози для культури на кожному полі [8, 10].

Третина всіх інноваційних розробок із захисту зернових культур, створених Їнститутом захисту рослин та багатьма іншими установами НААН (табл.), розташованими в різних грунтово-кліматичних зонах, дають підстави для вирішення широкого кола проблем щодо здійснення ефективних й екологічно безпечних захисних заходів та отримання додаткових урожаїв зерна покращеної якості. Розроблено методичні рекомендації щодо захисту культурних рослин, зокрема зернових культур, від нематодозів. Оптимізовані системи захисту зернових культур від бур'янів передбачають здійснення моніторингу сегетальної рослинності та встановлення структури забур'янення посівів, здійснення агротехнічних заходів та розробку регламентів застосування гербіцидів.

Розроблено зональні інтегровані системи захисту зернових культур (пшениця, ячмінь, тритикале, кукурудза, просо, овес, рис, соя, горох) від шкідників, хвороб та бур'янів, складовими яких є стабілізація структури посівних площ, дотримання агротехнічних вимог (сівозміна, обробіток грунту, удобрення, оптимальні строки сівби та збирання врожаю), широке використання стійких високопродуктивних сортів, застосування фунгіцидних, інсекто-фунгіцидних композицій, біопрепаратів та регуляторів росту рослин для передпосівної обробки насіння, постійний моніторинг фітосанітарного стану посівів, контроль бур'янів, обробка посівів у критичні періоди для розвитку хвороб та шкідників рослин. Ефект від трансферу створених інновацій може бути таким: чистий прибуток - від 3367-7950 до 12644,5 грн на 1 га (за умов зрошення), рентабельність - від 84,1 до 131-152\%.

За впровадження екологічно безпечних технологій захисту зерна від хвороб та шкідників при зберіганні важливими є такі заходи: дезінфекція незавантажених складів, більш досконалі способи моніторингу шкідливих організмів в умовах довготривалого зберігання, сумісне застосування інсектицидів і біопрепаратів на зерносховищах, мікрохвильове опромінення зерна, зберігання зерна у поліетиленових мішках-рукавах Ipesa Silo.

5. Хімічний метод захисту рослин. За інтенсивних технологій 
ефективний захист сільськогосподарських культур, зокрема зернових, здійснюють, насамперед, широким застосуванням пестицидів. На перший погляд цей метод забезпечує необхідний захисний ефект, дає можливість одержати швидкий господарський результат, є прийнятним за величиною затрат, проте створює і значні негативні наслідки [11]. Масоване застосування пестицидів сприяє забрудненню навколишнього середовища і разом із тим - вироблюваної продукції. Тому гостро постає потреба зменшення пестицидного навантаження на агроекосистему. Стосовно зернових культур у даному напрямі створено 19 інновацій, основна частина яких належить Їнституту захисту рослин НААН.

Розроблено технологічні регламенти застосування пестицидів сучасного асортименту для захисту основних сільськогосподарських культур, особливо зернових. Велике значення надається раціоналізації екологічної безпеки хімічного методу захисту: передпосівна обробка насіння фунгіцидними та інсектицидними протруйниками проти шкідників сходів, обробки посівів пестицидами в науково обгрунтовані строки, застосування сумішей пестицидів із біологічними препаратами. Розроблено модель оцінки ризику застосування пестицидів сучасного асортименту для захисту зернових культур, що базується на використанні екотоксикологічних критеріїв та інтегральних показників - ступеня небезпечності пестициду, середньозваженого ступеня небезпечності комбінованих препаратів, варіантів хімічного захисту окремих культур, агроекотоксикологічного індексу. До того ж застосування пестицидів зіставляється зі здатністю агроекосистеми до самоочищення. Розроблено методики визначення множинних залишків пестицидів у рослинах та врожаю (чутливість $0,005-0,2$ мг/кг, середнє значення $>80,0 \%$, довірчий інтервал при $n=15, P=0,95<2,0 \%)$, які дають можливість визначити якість протруєння насіннєвого матеріалу, оцінити стан агроценозів та контролювати продукцію урожаю за критерієм залишкових кількостей пестицидів. Здійснення трансферу створених інновацій дасть змогу оптимізувати хімічний захист зернових культур, більш ефективно захищати посіви від шкідливих організмів та отримувати додаткові врожаї покращеної якості.

6. Карантин рослин. Проблема вторгнення на нові території численних шкідливих організмів з чужини привертає увагу суспільства i завжди є актуальною внаслідок розвитку процесів глобалізації, зміни клімату, забруднення та деградації екосистем. На нових територіях чужинні види організмів можуть акліматизуватися, зайняти нові екологічні ніші та успішно конкурувати з місцевими видами, спричиняючи подекуди серйозні незворотні процеси в навколишньому середовищі на генетичному, видовому й екосистемному рівнях. Як наслідок, збитки, завдані чужинними видами, реєструються як в аграрному секторі, 
лісовому господарстві, так і в економіці в цілому. Значною мірою це стосується й зернового господарства України. Згідно з Міжнародною конвенцією із захисту рослин, Угодою про застосування санітарних та фітосанітарних заходів Світової організації торгівлі, підтримка карантинного статусу наведених у «Переліку ...» регульованих шкідливих організмів, розробка та запровадження заходів їх фітосанітарного контролю потребує технічного обгрунтування, основою яких $є$ багатопланові наукові дослідження, що розподіляються на три блоки: 1) обгрунтування фітосанітарного законодавства; 2) визначення заходів фітосанітарного контролю об’єктів регулювання; 3) розробка методів та способів локалізації й ліквідації вогнищ карантинних організмів [12].

Їнститутом захисту рослин та його мережею (Дослідна станція карантину винограду і плодових культур, Закарпатський територіальний центр карантину рослин, Українська науково-дослідна станція карантину рослин) упродовж останніх 15-ти років розроблено численні методичні рекомендації та інструкції з процедур проведення аналізу фітосанітарного ризику, діагностики та контролю розвитку карантинних шкідників зернових культур (західний кукурудзяний жук Diabrotica virgifera virgifera Le Conte, совки роду Spodoptera, зерноїди роду Callosobruchus, рисова нематода Aphelenchoides besseyi Chrictie, coєва нематода Heterodera glycines Ichinohe) та бур'янів (гірчак рожевий, сорго алепське, ценхрус якірцевий, амброзія полинолиста), обстеження сільськогосподарських угідь та складських приміщень на виявлення карантинних організмів, випробування сортів та гібридів кукурудзи на стійкість проти діабротики, знезараження зернобобової продукції. Створено також інформаційно-аналітичні бази «Карантинні види кукурудзяних жуків. Можливість акліматизації в південно-західному регіоні України», базу даних нових шкідливих організмів - веб-сервіс, автоматизовану картографо-інформаційну систему «Інтерактивний атлас. Карантинний стан рослин Одеської області», колекцію мікропрепаратів найбільш поширених шкідливих видів нематод (включаючи карантинні види нематод). Реалізація всієї названої науково-технічної продукції (29 інновацій) буде сприяти істотному покращенню широкомасштабної роботи Держпродспоживслужби України, спрямованої на охорону рослинних ресурсів країни і разом із тим - на вирішення продовольчих та екологічних проблем. Це буде також значним внеском у зміцнення зернового господарства країни.

\section{ВИСНОВКИ}

Їнновації із захисту зернових культур доцільно групувати за такими головними напрямами: прогнозування фітосанітарного стану посівів; наукове забезпечення селекції зернових культур на стійкість 
проти шкідників та збудників хвороб; біологічний метод захисту рослин; вдосконалені екологічно безпечні технології захисту зернових культур від шкідливих організмів; хімічний метод захисту рослин; карантин рослин.

Результатом здійснення трансферу цих інновацій є ефективний захист найважливіших зернових культур (пшениця, жито, ячмінь, горох, гречка, просо, кукурудза, соя) від шкідливих організмів у різних грунтово-кліматичних зонах України і разом із тим - одержання значної частини додаткової продукції покращеної якості та підвищення рентабельності виробництва.

Створена інвестиційно-інноваційна база даних із захисту зернових культур, яка складається із 155-ти наукових розробок, є підставою для успішного вирішення низки проблем стосовно зміцнення зернового господарства, а разом із тим аграрної галузі та економіки країни в цілому. Надалі вона буде поповнюватись, вдосконалюватись і зможе знайти своє місце на ринку науково-технічної продукції агропромислового комплексу України. Провідну роль у цій роботі завжди буде відігравати Науково-методичний центр Національної академії аграрних наук України «Захист рослин» в особі головної установи - Іेнституту захисту рослин.

\section{БІБЛІОГРАФІЧНИЙ СПИСОК}

1. Трибель С.О., Ретьман С.В., Борзих О.І., Стригун О.О. Стратегічні культури. Київ: Фенікс, Колобіг, 2012. 368 с., іл.

2. Трибель С.О., Стригун О.О. Захист рослин - реальний напрям збільшення виробництва рослинницької продукції. Захист і карантин рослин. Київ: ІЗР НААН, 2013. Вип. 59. С. 324-336.

3. Федоренко В.П. Перспективи ентомологічних досліджень в Україні. Захист і карантин рослин. Київ: ІЗР НААН, 2014. Вип. 60. С. 415-425.

4. Чайка В.М., Сядриста О.Б., Бакланова О.В., Мельник П.П. Шкодочинність фітофагів на озимині. Захист рослин. 2001. № 12. С. $1-2$.

5. Гаврилюк Л.Л., Круть М.В. Инновации в Украинском институте защиты растений. Защита и карантин растений. 2013. № 6. С. 9-10.

6. Борзих О.І., Ретьман С.В., Неверовська Т.М. та ін. Фітосанітарний стан агроценозів в Україні в умовах зміни клімату. Землеробство. Київ: ВП «Едельвейс», 2015. Вип. 1. С. 93-97.

7. Лісовий М.П. Шляхи підвищення реалізації біологічного потенціалу врожайності сільськогосподарських культур. Вісник аграрної науки. 2003. № 9. С. $20-22$.

8. Лісовий М.П., Трибель С.О. Інтегрований захист. Основа сучасних технологій. Захист рослин. 1998. № 5. С. 3-4. 
9. Федоренко В.П., Ткаленко Г.М., Конверська В.П. Біологічний захист основа фітосанітарної оптимізації агроценозів. Український ентомологічний журнал. 2011. № 1. С. 9-22.

10. Довідник із захисту рослин ; за ред. М.П. Лісового. Київ: Урожай, 1999. $744 \mathrm{c}$.

11. Іващенко О.О., Іващенко О.О. Майбутнє системи захисту рослин, екологічні аспекти. Карантин і захист рослин. 2015. № 9. С. 1-4.

12. Федоренко В.П., Пилипенко Л.А. Наукове забезпечення фітосанітарних служб ЄС та України: проблеми і перспективи. Карантин $і$ захист ростин. 2008. № 12. С. $1-3$.

\section{Борзых А.И., Круть М.В.}

Институт защиты растений НААН,

ул. Васильковская, 33, г. Киев, 03022, Украина, e-mail:m.v.krut@ukr.net

\section{База данных инновационных разработок по защите зерновых культур в Украине}

Цель. Проанализировать инновационные разработки по защите зерновых культур в Украине и на основе этого сформировать инвестиционно-инновационную базу данных. Методы. Анализ инновационных разработок Института защиты растений Национальной академии аграрных наук Украины и других учреждений Научно-методического центра «Защита растений» за 2001-2018 г2. Выделение тех из них, которые связаны с защитой зерновых культур от вредителей, болезней и сорняков. Группирование инноваций по защите зерновых культур по направлениям. Результаты. Созданная инвестиционно-инновационная база данных по защите зерновых культур в Украине состоит из 155 научных разработок, которые сгруппированы по таким направлениям: прогнозирование фитосанитарного состояния посевов; научное обеспечение селекции зерновых культур на устойчивость против вредителей и болезней; биологический метод защиты растений; усовершенствованные экологически безопасные технологии защиты зерновых культур от вредных организмов; химический метод защиты растений; карантин растений. Эффект от трансфера инноваций может быть таким: чистая прибыль - от 3367-7950 до 12644,5 грн на 1 га (в условиях орошения), рентабельность - от 84,1 до 131-152\%. Выводы. Результатом осуществления трансфера созданных инноваций является эффективная защита важнейших зерновых культур (пшенииа, рожь, ячмень, горох, гречиха, просо, кукуруза, соя) от вредных организмов в различных почвенно-климатических зонах Украины и вместе с этим - получение значительной 
части дополнительной продукиии улучшенного качества и повышение рентабельности производства. Это будет основой для успешного решения целого ряда проблем по укреплению как зернового хозяйства, так и аграрного сектора и экономики страны в целом.

инвестиционно-инновационная база данных, зерновые культуры, вредные организмы, прогноз, устойчивость против вредителей и болезней, биологический метод, химический метод, экологически безопасные технологии защиты, карантин растений

\section{Borzykh A., Krut M.}

Institute of Plant Protection of NAAS of Ukraine,

Vasylkivska st., 33, Kyiv, Ukraine, 03022,

e-mail:m.v.krut@ukr.net

\section{Database of investment and innovative developments on grain crop protection in Ukraine}

Goal. To perform innovative developments for the protection of grain crops in Ukraine and on this basis to generate the investment and innovation database. Methods. Analysis of innovation developments of Institute of Plant Protection of National Academy of Agrarian Sciences of Ukraine and other institutions of Scientific and Methodological Center "Plant Protection" during 2001-2018. Distinguishing of these, which are connected with grain crop protection from pests, diseases and weeds. Grouping of innovations on grain crop protection due to different fields. Results. Created investment and innovation database for the protection of grain crops in Ukraine consists of 155 scientific developments, which are grouped in the following areas: forecasting of phytosanitary condition of crops; providing scientific breeding of crops for resistance to pests and diseases; biological method of plant protection; advanced environmentally friendly technologies to protect crops against harmful organisms; chemical method of plant protection; plant quarantine. The effect of the transfer of innovation may be as follows: net profit from 3367-7950 till 12644,5 UAH per 1 ha (under irrigation), profitability - from 84.1 to 131$152 \%$. Conclusions. The result of the transfer of the created innovation is the effective protection of major crops (wheat, rye, barley, peas, buckwheat, millet, corn, soybeans) from pests in different soil-climatic zones of Ukraine and with all this obtaining a significant part of additional production of improved quality and increased profitability. This will be the basis for the successful solution of a number of problems of strengthening of grain farming and agricultural sector and the economy as a whole.

investment and innovative database, grain crops, harmful organisms, prognosis, resistance to pests and diseases, biological method, chemical method, environmentally friendly protection technologies, plant quarantine 


\section{REFERENCES}

1. Trybel S.O., Retman S.V., Borzykh O.I., Stryhun O.O. (2012). Stratehichni kultury. [Strategic cultures]. Kyiv: Feniks, Kolobig, 368 p. [in Ukrainian].

2. Trybel S.O., Stryhun O.O. (2013). Zakhyst roslyn - realnyi napriam zbilshennia vyrobnytstva roslynnytskoi produktsii. [Plant protection is a real straight of crop production]. Zakhyst $i$ karantyn roslyn. Kyiv: IZR NAAN. V. 59. P. 324-336. [in Ukrainian].

3. Fedorenko V.P. (2014). Perspectyvy entomologichnykh doslidzhen v Ukraini. [Perspectives of entomologic investigations in Ukraine]. Zakhyst $i$ karantyn roslyn. Kyiv: IZR NAAN. V. 60. P. 415-425. [in Ukrainian].

4. Chaika V.M., Siadrysta O.B., Baklanova O.V., Melnyk P.P. (2001). Shkodochynnist' fitofagiv na ozymyni. [Harmfulness of phytophages in winter wheat]. Zahist roslin. № 12. P. 1-2. [in Ukrainian].

5. Gavrilyuk L.L., Krut' M.V. (2013). Innovatsii v Ukrainskom institute zashchity rasteniy. [Innovations in Ukrainian Institute of Plant Protection]. Zashchita $i$ karantin rasteniy. № 6. P. 9-10. [in Russian].

6. Borzykh O.I., Retman S.V., Neverovska T.M. et al. (2015). Fitisanitarnyi stan afrotsenoziv v Ukraini v umovakh zminy klimatu. [Phytosanitary state of agrocoenosises in Ukraine in conditions of climate's change]. Zemlerobstvo. Kyiv: VP “Edelvei”. Vyp. 1. P. 93-97. [in Ukrainian].

7. Lisovyi M.P. (2003). Shliakhy pidvyshchennya realizatsii biologichnogo potentsialu vrozhainosti silskohospodarskykh kultur. [Ways to increase realization of the biological potential of agricultural crops' productivity]. Visnyk ahrarnoi nauky. № 9. P. 20-22. [in Ukrainian].

8. Lisovyi M.P., Trybel S.O. (1998). Intehrovanyi zakhyst. Osnova suchasnykh tekhnolohii. [Integrated protection. The bases of current technology]. Zakhyst roslyn. 1998. № 5. P. 3-4. [in Ukrainian].

9. Fedorenko V.P., Tkalenko H.M., Konverska V.P. (2011). Biolohichnyi zakhyst - osnova fitosanitarnoi optymizatsii ahrotsenoziv. [Biological protection is a bases of the agrocoenosises' phytosanitary optimization]. Ukrainskyi entomolohichnyi zhurnal. № 1. P. 9-22. [in Ukrainian].

10. Lisovyi M.P. (Ed.). (1999). Dovidnyk iz zakhystu roslyn. [Directory on plant protection]. Kyiv: Urozhai. 744 p. [in Ukrainian].

11. Ivashchenko O.O., Ivashchenko O.O. (2015). Maibutnie systemy zakhystu roslyn, ekolohichni aspekty. [Future of the system of plant protection, ecological aspects]. Karantyn i zakhyst roslyn. № 9. P. 1-4. [in Ukrainian].

12. Fedorenko V.P., Pylypenko L.A. (2008). Naukove zabezpechennia fitosanitarnykh sluzhb ES ta Ukrainy: problemy i perspektyvy. [Scientific providing of phytosanitary service of EC and Ukraine: the problems and perspectives]. Karantyn i zakhyst roslyn. № 12. P. 1-3. [in Ukrainian]. 